\title{
Haemagglutinating and Adhesive Properties Associated with the K99 Antigen of Bovine Strains of Escherichia coli
}

\author{
By M. R. BURROWS, R. SELLWOOD AND R. A. GIBBONS \\ Institute for Research on Animal Diseases, Compton, Nr Newbury, Berkshire
}

(Received I2 April I976)

\begin{abstract}
SUMMARY
The K99 antigen common to some bovine strains of Escherichia coli caused mannose-resistant haemagglutination of sheep erythrocytes and was shown to be responsible for the attachment of K99-positive bacteria to calf brush-border preparations because (i) strains grown at $18{ }^{\circ} \mathrm{C}$ did not produce K99 antigen, cause haemagglutination, or attach to brush borders; (ii) a K I $2\left(\mathrm{~K}_{99^{+}}\right)$recombinant strain showed both haemagglutinating activity and attachment to brush borders whereas, before it received the K99 plasmid, the recipient strain was negative in both respects; and (iii) cell-free extracts of K99 antigen showed haemagglutinating activity and inhibited the attachment of K99-positive organisms to brush borders.

K99 antigen appears to be a virulence determinant in the pathogenesis of neonatal calf diarrhoea. It is readily demonstrated by haemagglutination and brushborder attachment tests.
\end{abstract}

\section{INTRODUCTION}

Most strains of Escherichia coli isolated from calves with diarrhoea (Smith \& Halls, 1967) possess a common $\mathrm{K}$ antigen (Smith \& Linggood, 1972) which has been designated K99 (Ørskov et al., 1975). This antigen is transmissible and appears to be an important virulence determinant, probably because it enables K99-positive organisms to proliferate in the small intestine (Smith \& Linggood, 1972).

The rapid proliferation of K88-positive strains of $E$. coli in the small intestine of pigs with neonatal diarrhoea (Smith \& Jones, 1963) has been attributed to the ability of these organisms to attach to the intestinal epithelium (Arbuckle, 1970; Drees \& Waxler, 1970 $a, b$; Bertschinger, Moon \& Whipp, 1972). Furthermore the K88 antigen has been shown to be responsible for the attachment both in vivo (Jones \& Rutter, 1972) and in vitro (Jones, I972; Jones \& Rutter, 1972; Wilson \& Hohmann, I974; Sellwood et al., 1975).

It seems reasonable to assume that $\mathrm{K}_{99}$ antigen may function in calves in a similar manner to $\mathrm{K} 88$ antigen in pigs. The haemagglutinating properties of $\mathrm{K} 88$ have been documented by Stirm et al. (1967a), Jones (1972) and Jones \& Rutter (1974). Their results have indicated the usefulness of this test system in reflecting the adhesive properties of K88 antigen.

The object of this study was to investigate the haemagglutinating activity and morphology of K99 antigen and assess its significance in the attachment of K99-positive strains of $E$. coli to brush borders prepared from the epithelial cells of calf small intestine. 


\section{METHODS}

Strains of E. coli. Seven K99-positive enteropathogenic calf strains, characterized by Ørskov et al. (1975), and a KI 2 strain, kindly supplied by Dr H. Williams Smith, Houghton Poultry Research Station, Huntingdon, were used. The seven K99-positive strains were в4I [Oroi :K99], в42 [O9:K35,K99], в44 [O9:K30,K99], в85 [O9:K99], в79 [Oro : K32, K99], BI I I [OıI :K99], and BI 7 [O8:K85,K99].

The bacteria were grown on tryptose glucose yeast extract agar (TGXA; Schlechts \& Westphal, I966) modified to include the trace elements solution as used in Davis \& Mingioli's minimal media (Cruickshank, I965). Cultures were incubated at either $37^{\circ} \mathrm{C}$ or $18{ }^{\circ} \mathrm{C}$.

Preparation of antiserum. OK antisera against the seven K99-positive strains and against a KI2 K99-positive recombinant strain were raised by giving rabbits a series of intravenous injections containing approximately $10^{8}$ live organisms $/ \mathrm{ml}$ (Sojka, I965). O antisera were also prepared against $\mathrm{O}_{9}, \mathrm{O} 8$ and OroI antigens using boiled cultures of strains B44, BI I 7 and B4I.

Serological and haemagglutination tests. $\mathrm{O}$ and $\mathrm{K}$ agglutination tests and immunodiffusion tests were performed as described by Jones \& Rutter (1972). For immunodiffusion tests, bacterial suspensions were frozen and thawed three times. Microhaemagglutination tests were done as described by Jones \& Rutter (1974). Whole blood from guinea pigs, cows, fowl, goats and pigs was collected in sodium citrate $(3.8 \%, \mathrm{w} / \mathrm{v}$, in distilled water). Washed packed human $\mathrm{O}$ cells (kindly supplied by the Blood Transfusion Centre, Oxford) and defibrinated sheep blood (Wellcome Reagents, Beckenham, Kent) were also used.

Electron microscopy. Bacteria were prepared for electon microscopic examination using the method of Stirm et al. (1967a). Specimen grids were prepared by a modification of the method of Gregory \& Pirie (I973). The grids were metal shadowed in an AEI metrovac coating unit using gold-palladium alloy at an angle of $29^{\circ}$, and were examined in a Philips EM 300 electron microscope.

Cell-free K99 antigen. K99 antigen was extracted from KI2 $\left(\mathrm{K}_{99^{+}}\right)$and $\mathrm{B} 4 \mathrm{I}$ strains as described by Stirm et al. (1967 b) for K88 antigen, except that the precipitate was collected at $\mathrm{pH} 4.5$. The $\mathrm{K} 99$ antigen preparations were dissolved in $0.15 \mathrm{M}-\mathrm{NaCl}$ in phosphate buffer $\mathrm{pH} 7.0$ (containing $0.03 \mathrm{M}-\mathrm{Na}_{2} \mathrm{HPO}_{4}$ and $0.02 \mathrm{M}-\mathrm{KH}_{2} \mathrm{PO}_{4}$ ) and stored at $-20{ }^{\circ} \mathrm{C}$.

Transfer of $K 99$ plasmid. The prospective recipient strain of $E$. coli was a nalidixic-acidresistant mutant of a KI2 strain. The donor strain, B4I [OIOI:K99], was nalidixic-acidsensitive.

The K99 plasmid was transferred by inoculating $0.02 \mathrm{ml}$ of nutrient broth culture of KI 2 grown overnight and $0.02 \mathrm{ml}$ of a similar culture of B4I into $100 \mathrm{ml}$ of nutrient broth, and incubating at $37^{\circ} \mathrm{C}$ for $18 \mathrm{~h}$. This mated mixture was plated out on TGXA medium containing nalidixic acid ( $100 \mu \mathrm{g} \mathrm{ml}^{-1}$ ); and colonies were picked and examined for the presence of the $\mathrm{K} 99$ antigen by slide agglutination tests. The sugar fermentation reactions of the K99-positive nalidixic-acid-resistant organisms were compared with those of both the donor and recipient strains to check that the recombinant was a $\mathrm{KI} 2\left(\mathrm{~K}_{99^{+}}\right)$recombinant strain and not a nalidixic-acid-resistant mutant of strain B4I.

Brush-border adhesion test. Brush borders were prepared from the small intestine of calves (I to 2 days old), and the adhesion test was performed as described by Sellwood et al. (1975) except that the brush borders and the $E$. coli were finally washed and resuspended in phosphate buffer $\mathrm{pH}_{7} \cdot 0$. Bacterial suspensions contained approximately $10^{8}$ organisms $/ \mathrm{ml}$.

Inhibition of adhesion of K99-positive bacteria. A suspension ( $0.1 \mathrm{ml})$ of brush borders was centrifuged in a small conical tube and the supernatant fluid was discarded. K99 antigen 
Table I. The inhibition of haemagglutinating activity of K99-positive strains of

E. coli by selected antisera

Dilutions of antisera $(25 \mu \mathrm{l})$ were incubated with equal volumes of either 4 to 8 haemagglutinating units (I haemagglutinating unit is the highest dilution of test material which caused complete haemagglutination) of bacterial suspension or cell-free $\mathrm{K} 99$ antigen at $37^{\circ} \mathrm{C}$ for $2 \mathrm{~h}$, then cooled on ice and $25 \mathrm{ml}$ of a $3 \%(\mathrm{w} / \mathrm{v})$ suspension of red-blood cells was added. Haemagglutination inhibition (HI) titres were the highest dilutions of serum that inhibited haemagglutination after $\mathrm{I} h$ at 0 to $4^{\circ} \mathrm{C}$. Bacterial agglutinin titres were recorded after bacterial suspensions had been incubated at $4{ }^{\circ} \mathrm{C}$ overnight with $0.15 \mathrm{M}-\mathrm{NaCl}$, in place of red cells, and were expressed as the highest dilutions of serum causing bacterial agglutination. Titres are recorded as the reciprocal dilutions of antisera.

\begin{tabular}{|c|c|c|c|c|}
\hline \multirow[b]{2}{*}{ Strain } & \multicolumn{2}{|c|}{ B4I OK antiserum } & \multicolumn{2}{|c|}{ KI 2 (K99) OK antiserum } \\
\hline & Agglutinin titre & HI titre & Agglutinin titre & HI titre \\
\hline B4I & 1280 & 1280 & 5120 & 280 \\
\hline B42 & 1280 & 80 & 5120 & 26 \\
\hline B44 & 320 & 320 & 2560 & 24 \\
\hline B85 & 640 & 80 & 5120 & 140 \\
\hline B79 & 160 & 1280 & 1280 & 66 \\
\hline BI I I & 10 & IO & IO & 20 \\
\hline BII7 & 10 & IO & 10 & 80 \\
\hline KI $2\left(\mathrm{~K}_{99^{+}}\right)$ & 160 & 80 & 960 & I 24 \\
\hline Cell-free KI $2\left(\mathrm{~K}_{99}{ }^{+}\right)$ & NT & 160 & NT & 133 \\
\hline
\end{tabular}

NT, Not tested.

$(0.1 \mathrm{ml})$ or $\mathrm{K} 99$ antiserum $(0.1 \mathrm{ml})$ was added and the brush borders were resuspended and incubated at room temperature for $30 \mathrm{~min}$. A suspension ( $0 . \mathrm{I} \mathrm{ml})$ of $E$. coli strain $\mathrm{B} 4 \mathrm{r}$ was then added, and the mixture was transferred to a small screw-capped vial $(\mathrm{I} \times 3 \mathrm{~cm})$ and incubated at room temperature for $30 \mathrm{~min}$ on a rotary shaker operating at $30 \mathrm{rev}$. $\mathrm{min}^{-1}$. The number of bacteria attached to 20 brush borders was counted using phase-contrast microscopy. In control tests, phosphate buffer was substituted for K99 antigen. Inhibition of bacterial adhesion is expressed as the difference between the number of bacteria attached to brush borders in the control and the number attached in the test, as a percentage of the control.

\section{RESULTS}

Properties of K99-positive strains grown at $37^{\circ} \mathrm{C}$

Freeze-thawed suspensions of the seven K99-positive strains showed a single identical precipitin line with antisera prepared in rabbits against each of the seven K99-positive strains. This line was still demonstrable after the antisera had been absorbed with homologous boiled cultures but was not present after absorption with live B4I organisms.

The OK antisera prepared against the seven K99-positive strains cross-reacted in $\mathrm{K}$ agglutination tests to various degrees. Strains BI I I and BI 7 gave low titres $(<$ I/40) with homologous and heterologous antisera.

Bacterial suspensions of the K99-positive strains caused haemagglutination of sheep redblood cells; red cells from the other species tested either gave inconsistent results or did not show evidence of haemagglutination. The haemagglutination of sheep red-blood cells was not inhibited by the presence of $0.5 \%$ D-mannose, and did not completely elute at $37^{\circ} \mathrm{C}$ although titres were reduced. Titres against strains BIII and BII 7 were consistently lower than those against the other strains tested, and in some tests were less than $\mathrm{I} / \mathrm{IO}$, the lowest dilution tested. All samples of sheep cells tested were agglutinated by the K99-positive 
strains; a minimum average of between 0.3 and 3 bacteria per red cell was necessary for complete agglutination. Mannose-resistant (m.r.) haemagglutinating activity could be inhibited with antisera prepared against the homologous or heterologous live organisms (Table I). Haemagglutination was not inhibited by $\mathrm{O}$ antisera or by $\mathrm{OK}$ antisera previously absorbed with live K99-positive organisms.

All seven strains adhered to brush borders, although fewer organisms of strains B I I and BII7 adhered compared with the other strains. At dilutions of $\mathrm{KI}_{2}\left(\mathrm{~K}_{99^{+}}\right)$antiserum of less than I/IO, bacterial agglutination occurred, which might account for the observed inhibition of adhesion of strain B4I. At dilutions of antiserum of $\mathrm{I} / \mathrm{IO}$ or more, little or no agglutination occurred but adhesion of stıain B4I to brush borders was inhibited.

\section{Properties of the K99-positive strains grown at $18^{\circ} \mathrm{C}$}

Strains grown at $18^{\circ} \mathrm{C}$ do not produce the K99 antigen (Ørskov et al., 1975). Suspensions of such strains showed no evidence of precipitin lines against homologous or heterologous OK antisera. Strains also showed no evidence of K99 antigen in K agglutination tests. Agglutination was observed against homologous $\mathrm{OK}$ antisera and $\mathrm{OK}$ antisera prepared against strains having the same $O$ antigen: this was attributed to the presence of $O$ agglutinins in the antisera. These strains were also negative in haemagglutination tests and did not adhere to brush borders. When cultures grown at $18{ }^{\circ} \mathrm{C}$ were used to absorb homologous antisera, there was no reduction in the haemagglutination inhibition titres of $\mathrm{K}$ agglutination titres compared with those of unabsorbed OK antisera.

\section{Properties of the $\mathrm{KI} 2\left(\mathrm{~K}^{\circ} 9^{+}\right)$recombinant strain}

Before recombination, the $\mathrm{KI} 2$ recipient strain showed no precipitin lines in gel diffusion tests against $\mathrm{K} 99$ antiserum and did not show agglutinating, haemagglutinating or adhesive activity. The $\mathrm{KI} 2\left(\mathrm{~K}_{99^{+}}\right)$recombinant strain gave a single line in gel diffusion tests that was identical to the line given by the $\mathrm{K}_{99}{ }^{+}$strains, and agglutinated with $\mathrm{OK}$ antisera prepared against the other $\mathrm{K} 99$-positive strains. The $\mathrm{KI}_{2}\left(\mathrm{~K}_{99}{ }^{+}\right)$strain also showed m.r. haemagglutinating activity with sheep red-blood cells. This activity could be inhibited with $\mathrm{OK}$ antisera prepared against the other K99-positive strains. OK antisera prepared against the recombinant strain also inhibited the haemagglutinating activity of the other K99-positive strains (Table I). The recombinant strain adhered to calf brush borders, and adhesion could be inhibited with homologous antiserum and $\mathrm{OK}$ antiserum prepared against strain $\mathrm{B} 4 \mathrm{I}$ at a dilution of $\mathrm{I} / \mathrm{IO}$.

Electron micrographs of the $\mathrm{KI} 2\left(\mathrm{~K}_{99^{+}}\right)$strain showed fine branched filamentous projections covering the surface of the bacterial cell (Fig. I) similar to those seen in electron micrographs of the donor strain B4I (Fig. 2). There was no evidence of such surface structures in the $\mathrm{KI} 2$ recipient strain (Fig. 3 ).

\section{Properties of cell-free K99 antigen}

Cell-free K99 antigen gave a single identical line in gel diffusion against all the K99positive antisera. These preparations caused m.r. haemagglutination of sheep red-blood cells, which could be inhibited by OK antisera prepared against the seven K99-positive strains. The m.r. haemagglutinating activity of cell-free K99 antigen eluted completely at room temperature and at $37^{\circ} \mathrm{C}$. Cell-free $\mathrm{K}_{99}$ antigen also caused an $85 \%$ inhibition in the adhesion of strain B4I to calf brush-border preparations. 

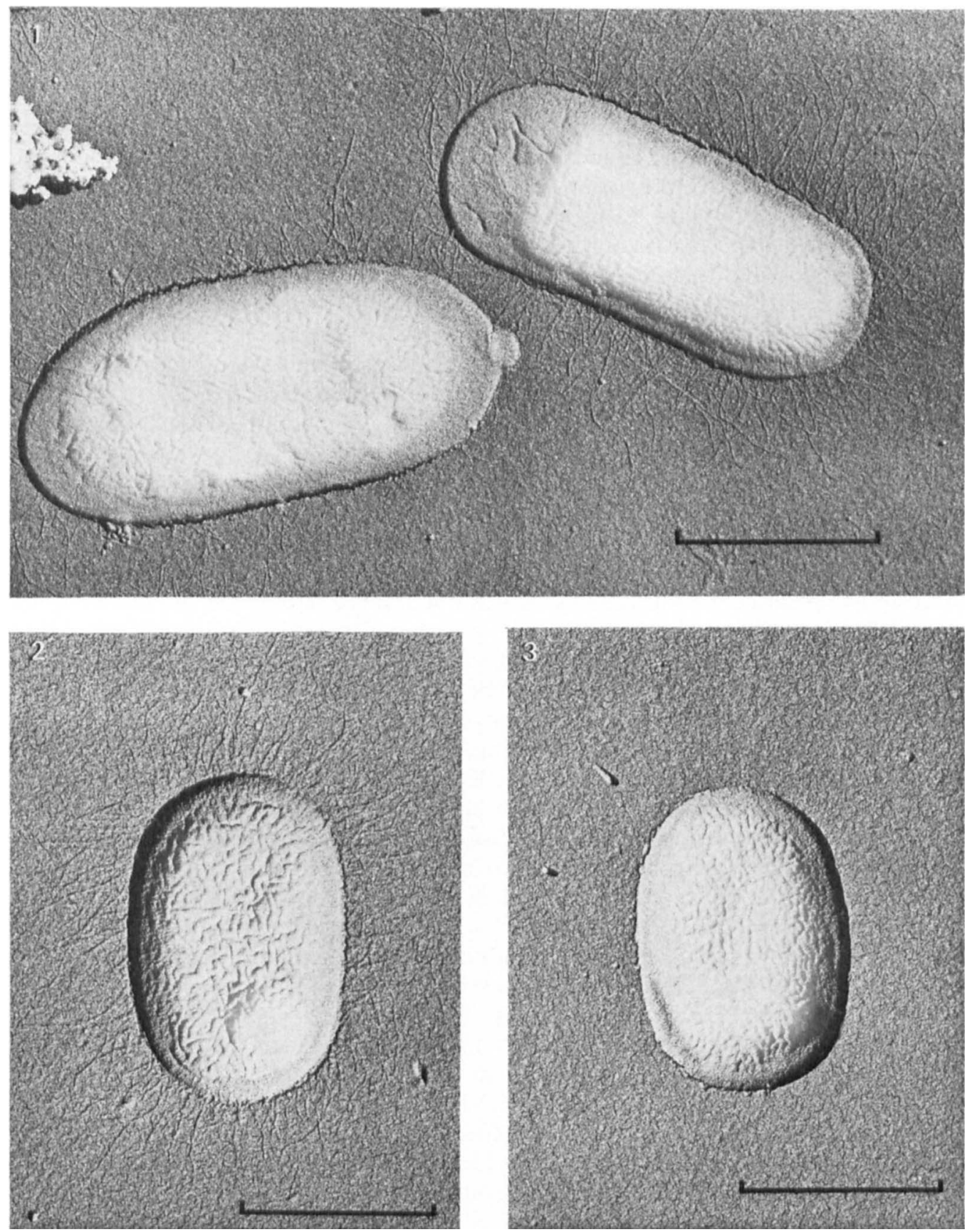

All bar markers represent $\mathrm{I} \mu \mathrm{m}$.

Fig. I. $\mathrm{K}_{1} 2\left(\mathrm{~K}_{99}{ }^{+}\right)$recombinant strain, showing fine filamentous surface structures of K99 antigen.

Fig. 2. B4I [OІоI:K99] donor strain.

Fig. 3. KI 2 recipient strain, showing no evidence of surface structures. 


\section{DISCUSSION}

When grown at $37^{\circ} \mathrm{C}$, the seven K99-positive strains of $E$. coli examined all caused m.r. haemagglutination of sheep red-blood cells and attached to brush borders prepared from the small intestine of calves. Two strains, BI I I and BI I 7, reacted poorly in $\mathrm{K}$ agglutination, haemagglutination and adhesion tests, possibly because they produce less K99 antigen than other strains. The haemagglutinating and adhesive properties were not exhibited by K99positive strains grown at $18{ }^{\circ} \mathrm{C}$, at which temperature the $\mathrm{K} 99$ antigen is not expressed (Ørskov et al., I975). Transfer of a plasmid specifying the K99 antigen to a K99-negative strain conferred both haemagglutinating and adhesive activity on the recombinant strain. This evidence suggests that the K 99 antigen is responsible for both the haemagglutinating and adhesive properties of the K99-positive E. coli strains. The inhibition of haemagglutination and adhesion by homologous and heterologous antisera, and the absence of haemagglutination inhibition by $\mathrm{O}$ and $\mathrm{OK}$ antisera previously absorbed with K99-positive live organisms, support our view that a common factor is responsible for both haemagglutination and adhesion.

Gel-diffusion studies showed that all the K99-positive strains possessed a single common antigen when tested against seven OK antisera. The KI 2 K99-positive recombinant strain gave an identical precipitin line against the same antisera. These precipitating antigens were absent from K99-positive strains grown at $18{ }^{\circ} \mathrm{C}$, and $\mathrm{K} 99$ antibody could not be absorbed from antisera by these bacteria. It was difficult to demonstrate precipitin formation with both cell-free $\mathrm{K} 99$ antigen and freeze-thawed bacterial suspensions - as it was with the K88 antigen of pig enteropathogenic E. coli (Ørskov et al., 197I). Electron micrographs suggest that the K99 antigen may be present on bacteria as filamentous surface structures, similar to the K88 antigen (Stirm et al., I967a). If so, the large molecular size of the antigen might inhibit its diffusion in agar gels.

The haemagglutinating activity of cell-free $\mathrm{K}_{99}$ antigen and its ability to inhibit adhesion of K99-positive organisms to brush borders suggest that, with live bacteria, this antigen is responsible for m.r. haemagglutination and adhesion to brush borders. However, the m.r. haemagglutinating activity of cell-free K99 antigen always eluted completely at room temperature and at $37^{\circ} \mathrm{C}$ whereas that of live K99-positive bacteria was inconsistently eluted at these temperatures. The reason for this difference is not known and is being investigated. K99-positive $E$. coli also adhere to brush borders prepared from the small intestine of pigs (Burrows \& Sellwood, unpublished observations) of both K88 adhesive and K88 nonadhesive phenotypes (Sellwood et al., 1975). However, these strains appear to be nonpathogenic for pigs (Smith \& Linggood, 197I) since the enterotoxin they produce does not dilate ligated intestinal loops in pigs (Smith \& Halls, 1967).

The K99 antigen of calf enteropathogenic strains of $E$. coli resembles the K88 antigen of pig enteropathogenic $E$. coli (Jones \& Rutter, 1974) in its ability to adhere to intestinal epithelium, its haemagglutination properties and its filamentous structure. The K99 antigen may function in a similar manner to the K88 antigen by allowing adhesion of $E$. coli to the small intestine in vivo (Jones \& Rutter, 1972) and thus enabling the organisms to proliferate and colonize the mucosa. The $\mathrm{K}_{99}$ antigen may therefore be regarded as a virulence determinant in the pathogenesis of neonatal calf diarrhoea.

We thank Dr J. M. Rutter and Dr G. W. Jones for advice and helpful discussions. We are also grateful to Mrs J. Hedges and Mrs M. Wheeler for technical assistance and to Mr R. D. Harrison for the electron micrographs. 


\section{REFERENCES}

Arbuckle, J. B. R. (1970). The locauon of Escherichia coli in the pig intestine. Journal of Medical Microbiology 3, 333-340.

Bertschinger, H. U., Moon, H. W. \& WhIPP, S. C. (1972). Association of Escherichia coli with the small intestinal epithelium. I. Comparison of enteropathogenic and non-enteropathogenic porcine strains in pigs. Infection and Immunity 5, 595-605.

CRUICKSHANK, R. (1965). Medical Microbiology, I Ith edn, p. 739. Edinburgh and London: Livingstone.

Drees, D. T. \& WAXLER, G. L. (I970 a). Enteric colibacillosis in gnotobiotic swine: a fluorescent microscopic study. American Journal of Veterinary Research 31, I I47-I I 57.

Drees, D. T. \& WAXLeR, G. L. (1970 $b$ ). Enteric colibacillosis in gnotobiotic swine: an electron microscopic study. American Journal of Veterinary Research 3I, I I 59-I I 7I.

Gregory, D. W. \& PIRIE, B. J. S. (I973). Wetting agents for biological electron microscopy. II. Shadowing. Journal of Microscopy 99, 267-278.

JONES, G. W. (1972). The adhesive properties of K88 antigen of strains of Escherichia coli pathogenic to neonatal pigs. Ph.D. thesis, University of Reading.

JONES, G. W. \& RUTTER, J. M. (1972). Role of the K88 antigen in the pathogenesis of neonatal diarrhoea caused by Escherichia coli in piglets. Infection and Immunity 6, $918-927$.

Jones, G. W. \& RutTER, J. M. (I974). The association of K88 antigen with haemagglutinating activity in porcine strains of Escherichia coli. Journal of General Microbiology 84, I35-I44.

$\emptyset_{\mathrm{RSKOV}}, \mathrm{F}$., ØRSKOV, I., JANN, B. \& JANN, K. (I97I). Immunoelectrophoretic patterns of extracts from all Escherichia coli $\mathrm{O}$ and $\mathrm{K}$ antigens test strains correlated with pathogenicity. Acta pathologica et microbiologica scandinavica B 79, I42-I52.

ØRskov, F., Ørskov, I., Smith, H. W. \& SojkA, W. J. (1975). The establishment of K99, a thermolabile, transmissible Escherichia coli $\mathrm{K}$ antigen, previously called ' $\mathrm{KCo}$ ', possessed by calf and lamb enteropathogenic strains. Acta pathologica et microbiologica scandinavica B 83, 31-36.

SCHLECHTS, S. \& WeSTPHAL, O. (1966). Wachstum und Lipopolysaccharid-(O-antigen)-gehalt von Salmonellen bei Züchtung auf Agarnährboden. Zentralblatt für Bakteriologie, Parasitenkunde, Infektionskrankheiten und Hygiene (Abteilung I) 200, 241-259.

Sellwood, R., Gibbons, R. A., Jones, G. W. \& Rutter, J. M. (1975). Adhesion of enteropathogenic Escherichia coli to pig intestinal brush borders: the existence of two pig phenotypes. Journal of Medical Microbiology 8, 405-4I I.

Smith, H. Williams \& Halls, S. (1967). Observations by the ligated intestinal segment and oral inoculation methods on Escherichia coli infections in pigs, calves, lambs and rabbits. Journal of Pathology and Bacteriology 93, 499-529.

Smith, H. Williams \& JoNes, J. E. T. (1963). Observations on the alimentary tract and its bacterial flora in healthy and diseased pigs. Journal of Pathology and Bacteriology 86, 387-41 2.

Smith, H. Williams \& Linggood, M. A. (I97I). Observations on the pathogenic properties of the K88, Hly and Ent plasmids of Escherichia coli with particular reference to porcine diarrhoea. Journal of Medical Microbiology 4, 467-485.

Smith, H. Williams \& LingGood, M. A. (1972). Further observations on Escherichia coli enterotoxins with particular regard to those produced by atypical piglet strains and by calf and lamb strains: the transmissible nature of these enterotoxins and of a $\mathrm{K}$ antigen possessed by calf and lamb strains. Journal of Medical Microbiology 5, 243-250.

Sojka, W. J. (1965). Escherichia coli in Domestic Animals and Poultry, review series no. 7. Farnham Royal: Commonwealth Bureaux of Animal Health.

Stirm, S., Ørskov, F., Ørskov, I. \& Birch-ANDersen, A. (1967 a). Episome-carried surface antigen K88 of Escherichia coli. III. Morphology. Journal of Bacteriology 93, 740-748.

StIRM, S., ØRSkov, F., Ørskov, I. \& MANSA, B. (1967 b). Episome-carried surface antigen of K88 of Escherichia coli. II. Isolation and chemical analysis. Journal of Bacteriology 93, 73 I-739.

Wilson, M. R. \& HoHmanN, A. W. (1974). Immunity to Escherichia coli in pigs; adhesion of enteropathogenic Escherichia coli to isolated intestinal epithelial cells. Infection and Immunity ro, 776-782. 